\title{
Deletion in Blood Mitochondrial DNA in Kearns-Sayre Syndrome
}

\author{
NATHAN FISCHEL-GHODSIAN, M. CHARLOTTE BOHLMAN, TONI R. PREZANT, \\ JOHN M. GRAHAM, JR., STEPHEN D. CEDERBAUM, AND MATTHEW J. EDWARDS
}

\begin{abstract}
Ahmanson Department of Pediatrics and Medical Genetics Birth Defect Center, Steven Spielberg Pediatric Research Center, Cedars-Sinai Medical Center and UCLA School of Medicine, Los Angeles, California 90048 [N.F-G., M.C.B., T.R.P., J.M.G.]; Department of Pediatrics and Psychiatry and the Mental Retardation Research Center, UCLA School of Medicine, Los Angeles, California 90024 [S.P.C.]; and Newcastle and New South Wales Genetics Services, Waratah. New South Wales, Australia [M.J.E.]
\end{abstract}

\begin{abstract}
Mitochondrial DNA deletions have been described in the Kearns-Sayre syndrome (KSS) and the Pearson's marrow-pancreas syndrome. In some cases, the same 4977-bp deletion has been identified in these two very different diseases. Therefore, it is not currently possible to predict the clinical phenotype from the size or location of the deletion. Instead, differential tissue distribution of the deletion has been implicated as one possible determinant of phenotype. In particular, in KSS the deletions have not been detected by Southern blotting in the blood, whereas in Pearson's syndrome they are easily detectable. We describe here an 11-y-old boy with clinically characteristic KSS and a 7.4-kb mitochondrial DNA deletion between nucleotides 7194 and 14595 . Southern blotting reveals that $75 \%$ of the mitochondrial DNA molecules from his peripheral blood have this deletion. This case blurs further the molecular distinction between the KSS and Pearson's marrow-pancreas syndrome, questioning whether tissue distribution is a sufficient explanation for the very different phenotypes of these disorders. (Pediatr Res 31: 557-560, 1992)
\end{abstract}

\section{Abbreviations}

mtDNA, mitochondrial DNA

KSS, Kearns-Sayre syndrome nt, nucleotide

EBV, Epstein-Barr virus

PCR, polymerase chain reaction

KSS is a multisystem mitochondrial disorder characterized by juvenile onset, progressive external ophthalmoplegia, and pigmentary retinal degeneration, and frequently accompanied by encephalopathy, ataxia, and heart block (1). In many of these patients, a heteroplasmic mtDNA deletion can be detected (25 ). The percentage of normal mtDNA to mtDNA with deletion varies between individuals (3), from tissue to tissue within the same individual (4), and over time (6). The size of the deletion varies also between affected individuals $(1,3)$. The relation between severity of disease and size and quantity of mtDNA deletions is not clear. In KSS, a high proportion of mtDNA deletions are found consistently in the most affected tissues, e.g. brain and muscle, whereas low or undetectable amounts are found consistently in some unaffected tissues, e.g. peripheral blood $(2,4-7)$.

Received October 8, 1991; accepted January 15, 1992

Correspondence: Nathan Fischel-Ghodsian, M.D. Department of Pediatrics, Cedars-Sinai Medical Center, 8700 Beverly Blvd., Los Angeles, CA 90048.
Pearson's marrow-pancreas syndrome is phenotypically an entirely different mitochondrial disorder, with refractory sideroblastic anemia, exocrine pancreatic insufficiency, and liver dysfunction, usually leading to death in infancy (8). However, the molecular defects are similar to those seen in KSS, with the most common 4977 -bp deletion from nt 8482 to nt 13460 being identical in both disorders $(8,9)$. The abnormal mtDNA molecules can be detected in most tissues and, in contrast to KSS, are always predominant in the peripheral blood $(8-10)$.

In this report we describe a patient with clinically typical KSS, associated with a previously undescribed distribution of deleted mtDNA molecules in this disease. The high proportion of abnormal mtDNA molecules in the peripheral blood of this patient, without associated clinical or laboratory abnormalities, indicates that tissue distribution may not always be a sufficient explanation for the different phenotypes of KSS and Pearson's marrowpancreas syndrome.

\section{MATERIALS AND METHODS}

Case report. M.F., born in 1979 , was the 3150 -g product of a normal third pregnancy to healthy, unrelated parents. He has an older, healthy brother and a sister who died at $9 \mathrm{~d}$ from transposition of the great arteries. Growth delay was noted at $18 \mathrm{mo}$ of age, and his height has remained 3-4 SD below the reference mean, with weight at the 5th percentile. Early psychomotor development was normal, but speech development was delayed. Progressive hearing loss was diagnosed at 6 y of age, when a learning deficit was also noted. At 9 y of age, mild ptosis and ophthalmoplegia, moderate retinal pigmentary degeneration, general muscle weakness, and ataxia with intention tremor were diagnosed. Those features progressively worsened over the next $2 \mathrm{y}$, and by $11 \mathrm{y}$ of age he was functioning intellectually at the 7 -y age level.

Laboratory investigations showed normal electrolytes, mildly elevated serum lactate $(2.29 \mathrm{mmol} / \mathrm{L}$, with normal up to 1.78 $\mathrm{mmol} / \mathrm{L})$, normal pyruvate $(68 \mu \mathrm{mol} / \mathrm{L})$, an elevated lactate:pyruvate ratio of 33.7 , and markedly elevated creatine kinase $(8.84 \mu \mathrm{kat} / \mathrm{L})$. Plasma amino acids and a glucose tolerance test were normal. A peripheral leukocyte karyotype was normal. A peripheral blood count showed a white blood cell count of $5.1 \times$ $10^{9} / \mathrm{L}$, platelet count of $232 \times 10^{9} / \mathrm{L}, \mathrm{Hb}$ of $132 \mathrm{~g} / \mathrm{L}$, hematocrit of 0.38 , mean corpuscular volume of $87.4 \mathrm{fL}$, mean corpuscular $\mathrm{Hb}$ of $30.1 \mathrm{pg}$, and a red blood cell distribution width of $12.4 \%$. Blood smears stained with Wright-Giemsa and with Prussian blue were normal. Serum iron was $14.7 \mu \mathrm{mol} / \mathrm{L}$, iron binding capacity was $41.0 \mu \mathrm{mol} / \mathrm{L}$, and ferritin was $45 \mu \mathrm{g} / \mathrm{L}$. Cerebrospinal fluid was acellular, had an elevated protein level of $1.71 \mathrm{~g} / \mathrm{L}$, glucose of $3.05 \mathrm{mmol} / \mathrm{L}$, pyruvate of $136 \mu \mathrm{mol} / \mathrm{L}$, and lactate of $4.44 \mathrm{mmol} / \mathrm{L}$. Magnetic resonance imaging scan was normal, 
except for a symmetrical increase in the T2 signal in the anterior basal ganglia. Electroretinography revealed a low amplitude, a late photopic response, and a barely recordable scotopic response. Muscle biopsy from the left quadriceps showed widely scattered ragged-red fibers on a modified Gomori's trichrome stain, characterized by increased subsarcolemmal mitochondria. When stained with the succinate dehydrogenase reaction, these fibers as well as others reveal increased staining. The percentage of fibers showing increased overall or subsarcolemmal staining was estimated at 3\%. Electron microscopy showed scattered fibers containing gigantic mitochondria with crystalline inclusions.

Materials. Restriction enzymes were obtained from Bethesda Research Laboratories (Gaithersburg, MD) and Boehringer Mannheim (Indianapolis, IN). Primers used for the PCR were from Operon Technologies (Alameda, CA). ( $\left.\alpha^{32} \mathrm{P}\right)$-dCTP $(3000$ $\mathrm{Ci} / \mathrm{mmol})$ and $\left(\alpha^{35} \mathrm{~S}\right)$-dATP $(800 \mathrm{Ci} / \mathrm{mmol})$ were purchased from New England Nuclear/Dupont (Boston, MA).

Cell lines and tissue samples. Lymphoblastoid cells were immortalized by transformation with EBV $(11,12)$. For all specimens, informed consent was obtained.

miDNA analysis by Southern blotting. Patient DNA was extracted from $2 \times 10^{7}$ EBV-transformed lymphoblastoid cells, 10 $\mathrm{mL}$ of whole blood, $20 \mathrm{~mL}$ of urine, swabs of cheek mucosa, and scraped-off material from unstained muscle slides by standard techniques (13). DNA was also extracted from EBV-transformed lymphoblastoid cells from both parents and from peripheral blood of the brother. One $\mu \mathrm{g}$ each of patient and parent DNA obtained from the lymphoblastoid cell lines was used for digestion with different restriction enzymes according to the manufacturer's conditions. The digested samples were electrophoresed through a $0.6 \%$ agarose gel and transferred to nylon filters (MSI MagnaNT; Micron Separations Inc., Westboro, MA). The filters were hybridized with $106 \mathrm{cpm} / \mathrm{mL}$ of labeled probe overnight at $65^{\circ} \mathrm{C}$, washed in $0.1 \% \mathrm{SDS} / 0.1 \times \mathrm{SSC}(3 \mathrm{M} \mathrm{NaCl}$, $0.3 \mathrm{M} \mathrm{Na}$ citrate) at $65^{\circ} \mathrm{C}$, and exposed for 4 to $6 \mathrm{~h}$ to Kodak XAR-5 film with two Lightning Plus intensifying screens at $-70^{\circ} \mathrm{C}$. The probes were prepared by amplifying $1 \mu \mathrm{g}$ of normal genomic DNA with the thermostable Taq DNA polymerase (Perkin Elmer Cetus, Norwalk, CT) and with either primer pairs 5 860-5 879 and 7 492-7 473, flanking the cytochrome oxidase subunit I gene, or primer pairs $10196-10215$ and 12 77912760 , flanking the NADH dehydrogenase subunits 4 and $4 \mathrm{~L}$, in a thermal cycler (Perkin Elmer Cetus) with an initial denaturation step at $98^{\circ} \mathrm{C}$ for $5 \mathrm{~min}$ and 35 three-step cycles of denaturation at $94^{\circ} \mathrm{C}$ for $30 \mathrm{~s}$, annealing at $54^{\circ} \mathrm{C}$ for $60 \mathrm{~s}$, and extension at $64^{\circ} \mathrm{C}$ for $180 \mathrm{~s}$. The probe was labeled with $\left(\alpha^{32} \mathrm{P}\right)$-dCTP by the multiprime method (Amersham Corp., Arlington Heights, IL). The patterns obtained after Southern blot hybridization were analyzed based on the human mtDNA sequence (14). The proportion of deleted mtDNA molecules was estimated densitometrically by scanning each lane on the autoradiogram with a Helena EDC densitometer (Helena Laboratories, Beaumont, TX) and then integrating the area under each peak by computer. $m t D N A$ analysis by direct $P C R$ sequencing. Direct sequencing of a double-stranded, undigested PCR fragment was performed using the dideoxy-mediated chain-termination method and $\left(\alpha^{35} \mathrm{~S}\right)$-dATP according to the manufacturer's protocol (Sequenase version 2.0 DNA sequencing kit; United States Biochemical Corp., Cleveland, $\mathrm{OH}$ ).

\section{RESULTS}

Deletion characterization. Patient and parent DNA obtained from the lymphoblastoid cell lines was used for digestion with each of the restriction enzymes PvuII, EcoRI, HindIII, HpaI, $B a m H I, X b a I, D r a I, N c o I$, and BglII. In the patient only, every digest generated abnormal sized fragments in addition to the expected normal sized fragments. With $P v u \mathrm{II}$, which cuts only at position 2652 , an abnormal 9-kb fragment was obtained, indicating a deletion of approximately $7.5 \mathrm{~kb}$. This was con- firmed with the other digests, and the breakpoints of the deletion were placed approximately at nt 7000 and 14500 . Two primers that are 10066 bp apart at positions $5860-5879$ and 15 92615907 were used for PCR. A 2 660-bp fragment was obtained, which presumably spans the deletion breakpoint. This fragment was first analyzed by digestion with the restriction enzymes PstI, HindIII, AccI, and HaelI, electrophoresis in 1.2\% agarose, and visualization of the resulting products by ethidium bromide staining. This localized the deletion breakpoints to nt $6964-$ 7198 and 14 370-14 604. To precisely define the breakpoints, the double-stranded, undigested PCR fragment was sequenced directly with a sequencing primer at 6 900-6 919. The sequence corresponded to the normal Cambridge sequence till nt 7193 and then continued from nt 14596 . This defined the deletion as a 7 402-bp deletion between nt 7194 and 14595 (Fig. 1). Sequence analysis showed the presence of a phenylalanine (TTT) at the $5^{\prime}$ end of the deletion in the sequence coding for the cytochrome $c$ oxidase 1 subunit, followed by asparagine (AAT) and a termination signal (AGG). Sequence analysis also revealed the absence of a direct repeat at the breakpoint, but showed the presence of one complete 5-bp and two incomplete 5- and 6-bp inverted repeats, which might form a stable stem loop structure.

Tissue distribution. Using the primers at 5860-5 879 and 15926-15907, the presence of the 2660 -bp deletion fragment was detected by PCR in all available tissues of the patient, e.g. muscle, peripheral blood, urine, and cheek mucosa. The relative proportions of wild-type to deleted mitochondrial chromosomes were assayed by Southern blotting after PvuII digestion and hybridization with a probe external to the deletion at 14715 15 926. Muscle could not be assayed because of the insufficient amount of undegraded DNA available. Autoradiographic data is shown in Figure $2 A$, and the relative proportions obtained by densitometry are shown in Figure $2 B$. Interestingly, the proportion of abnormal mtDNA molecules in peripheral blood is $75 \%$.

Family data. Lymphoblastoid cell lines from both parents and peripheral blood from the brother were assayed by PCR for the presence of the deletion as described above. No 2660 -bp deletion fragment was detected.

\section{DISCUSSION}

Molecular analysis of this patient with clinically characteristic KSS demonstrates the heteroplasmic presence of a $7402-b p$ deletion between nt 7194 and 14595 . The mitochondrial chromosomes with the deletion, therefore, preserve the promoters of heavy- and light-strand transcription, the $12 \mathrm{~S}$ and $16 \mathrm{~S}$ ribosomal RNA genes, and the origins of heavy-and light-strand replication. This is a feature common to nearly all of the described mitochondrial deletions and probably represents the requirement for competent replication. The mechanism of deletion formation in our patient is unclear. Direct repeats of 8- to 13-bp nt were described at the deletion breakpoints of KSS patients and patients with the Pearson's marrow-pancreas syndrome (15-17). The presence of the small, inverted repeats close to the breakpoints of the deletion in our patient are possible sites for the formation of a stem loop structure. Such an intrachromosomal structure, followed by excision of the loop DNA, could lead to the described deletion.

The distribution of the abnormal mitochondrial chromosome in our patient eliminates the previously used molecular distinction between KSS and Pearson's marrow-pancreas syndrome. Previous investigators had shown that the same mtDNA deletion can occur in both of these syndromes $(3,9)$. The differential phenotypic expression has generally been ascribed to the different tissue distribution of the deleted mtDNA molecules, in particular the presence of a large proportion of such molecules in the blood of patients with Pearson's syndrome and a tiny proportion in those with $\operatorname{KSS}(2,4-10)$. However, in our patient, $75 \%$ of the mtDNA molecules in the peripheral blood have a large deletion without any corresponding phenotype. 
A

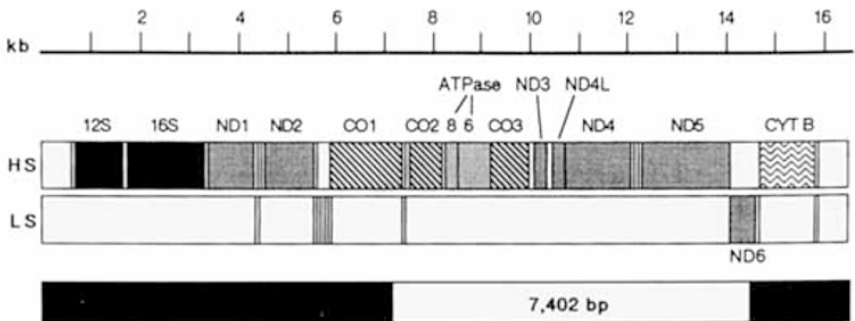

B

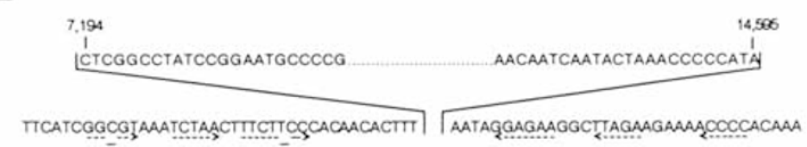
A c G T

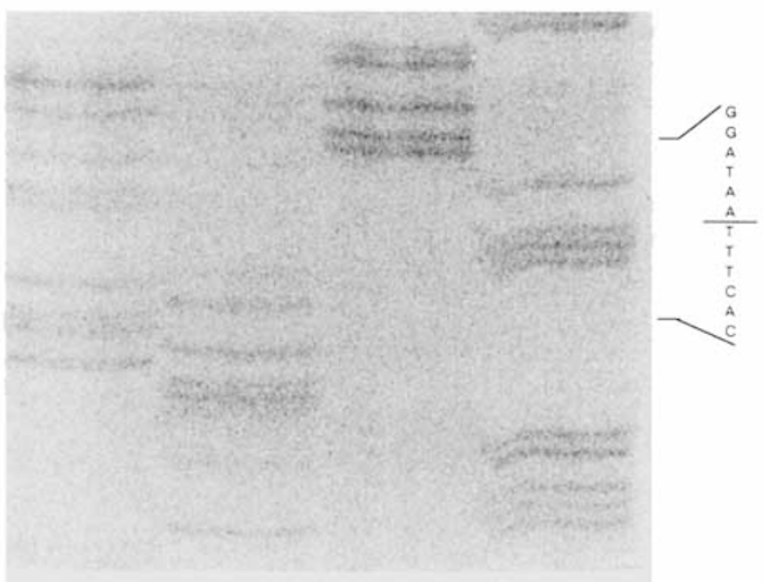

Fig. 1. Localization and breakpoint sequence of mtDNA deletion in a patient with KSS. A, Linearized map of the mitochondrial genome. The scale at the top is in $\mathrm{kb}$. The upper and middle bars represent the heavy and light strands of mtDNA, respectively, showing the genes for the subunits of NADH-coenzyme $\mathrm{Q}$ reductase $(N D)$, cytochrome $c$ oxidase $(C O)$, cytochrome $b(C Y T B)$, ATP synthase (ATPase), and the $12 \mathrm{~S}$ and $16 \mathrm{~S}$ ribosomal RNA. The transfer RNA are denoted by the small, open boxes. The lower bar depicts the patient's mtDNA, with the deletion depicted in white and the nondeleted regions depicted in black. The size of the deletion is indicated. $B$ shows the $5^{\prime}$ and $3^{\prime}$ sequences of the deletion in the upper line, with the numbers indicating the position of the first and last nt deleted. The flanking sequences immediately adjacent to the deletion breakpoint are shown in the lower line. The nt possibly involved in a stem loop formation are underlined, with the direction of the pairing indicated by the arrows. $C$, Autoradiograph of a DNA sequencing gel in the region of the deletion breakpoint. The sequence (dideoxy reactions $\mathrm{A}, \mathrm{C}, \mathrm{G}$, and $\mathrm{T}$ ) is of the $\mathrm{L}$ strand, reading $5^{\prime}$ to $3^{\prime}$ from bottom to top.

How then do mtDNA deletions exert their effects on cellular function? It has been shown that deleted genomes are transcribed, but not translated (18). In addition, they appear to interfere with the translation of wild-type mitochondrial genomes in the same cell (19). Just as deleted mtDNA can inhibit the function of normal mtDNA, a small number of defective cells in a tissue such as muscle can interrupt the function of many normal cells. In contrast, hematopoietic cells might not be affected by neighboring cells carrying abnormal mitochondrial genomes. Shoubridge et al. (19) showed that the proportion of abnormal to normal mitochondrial genomes in affected muscle cells is about 10 to 1 , with the level of normal genomes being similar to that
A

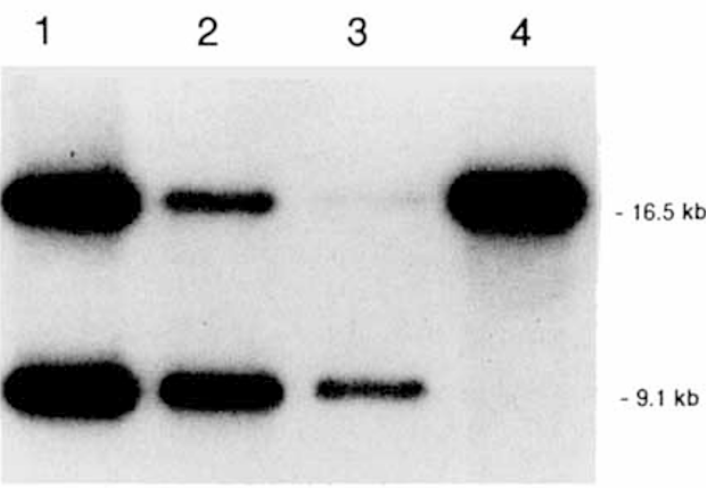

B

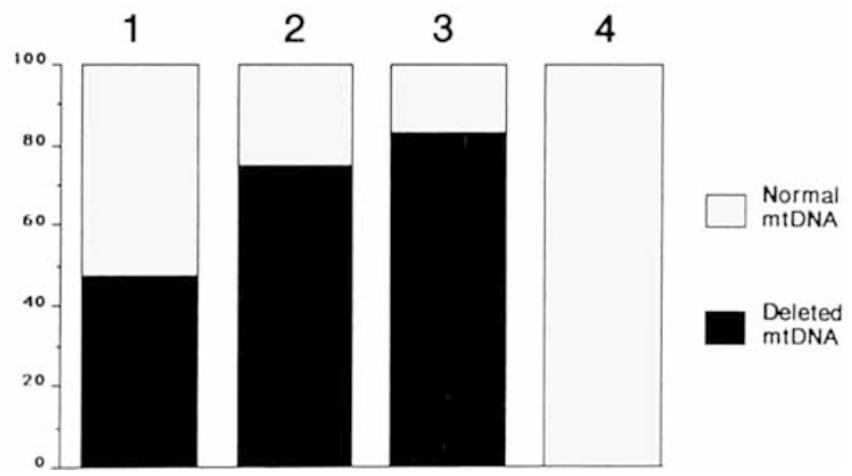

Fig. 2. Tissue distribution of deleted mtDNA molecules. $A$, Autoradiograph after digestion with $P v u$ II, Southern blotting, and hybridization with a probe external to the deletion. 1 , EBV-transformed lymphoblastoid cell line of the patient; 2 , peripheral blood of the patient; 3 , urine of the patient; and 4 , peripheral blood of the unaffected brother of the patient. $B$, Histogram representation of the relative proportions of normal (16.5-kb fragments) to abnormal (9.1-kb fragments) mitochondrial chromosomes from $A$.

in unaffected cells. Thus, a minority of cells with large amounts of deleted mtDNA molecules can be responsible for an overall high proportion of deleted mtDNA molecules.

Although one patient with the Pearson's marrow-pancreas syndrome had essentially no normal mitochondrial genomes in bone marrow and peripheral blood cells (10), another patient had blood cell proportions of normal to abnormal mitochondrial genomes similar to our patient, but had severe anemia, neutropenia, and thrombocytopenia (8). Neither tissue distribution nor percentage of the deleted mitochondrial genome can explain the hematologic phenotype. We are thus left to speculate that either the time of appearance of the abnormal mitochondrial genomes during ontogenesis is important or nuclear factors interact with the mitochondrial defect and modulate its expression. Alternatively, the same overall proportion of normal to deleted mtDNA molecules in the peripheral blood can be caused by a small proportion of cells with very high amounts of deleted mtDNA genomes, or by a majority of cells having lower amounts of deleted mtDNA genomes. Periodic reevaluation of the hematologic status and the amount of heteroplasmy in the peripheral blood of our patient, coupled with biochemical and enzymatic investigations, and the analysis of single cells might shed light on the genotype-phenotype relationship.

\section{REFERENCES}

1. Moraes CT, DiMauro S, Zeviani M, Lombes A, Shanske S, Miranda AF, Nakase H, Bonilla E, Werneck L, Servidei S, Nonaka I, Koga Y, Spiro AJ, Brownell KW, Schmidt B, Schotland DL, Zupanc M, DeVivo DC, Schon EA. Rowland LP 1989 Mitochondrial DNA deletions in progressive external 
ophthalmoplegia and Kearns-Sayre syndrome. N Engl J Med 320:12931299

2. Hurko O, Johns DR, Rutledge SL, Stine OC, Peterson PL, Miller NR, Martens ME, Prachman PB, Brown RH, Lee CP 1990 Heteroplasmy in chronic external ophthalmoplegia: clinical and molecular observations. Pediatr Res 28:542-548

3. Zeviani M, Moraes CT, DiMauro S, Nakase H, Bonilla E, Schon EA, Rowland LP 1988 Deletions of mitochondrial DNA in Kearns-Sayre syndrome. Neurology 38:1339-1346

4. Shanske S, Moraes CT, Lombes A, Mirada AF, Bonilla E, Lewis P, Whelan MA, Ellsworth CA, DiMauro S 1990 Widespread tissue distribution of mitochondrial DNA deletions in Kearns-Sayre syndrome. Neurology 40:2428

5. Johns DR 1990 mtDNA deletions in Kearns-Sayre. Neurology 40:1322-1323

6. Larsson N-G, Holme E. Kristiansson B, Oldfors A, Tulinius M 1990 Progressive increase of the mutated mitochondrial DNA fraction in Kearns-Sayre syndrome. Pediatr Res 28:131-136

7. Poulton J, Deadman ME, Turnbull PM, Lake B, Gardiner RM 1991 Detection of mitochondrial DNA deletions in blood using the polymerase chain reaction: non-invasive diagnosis of mitochondrial myopathy. Clin Genet 39:3338

8. Roetig A, Cormier V, Blanche S, Bonnefont J-P, Ledeist F, Romero N, Schmitz J, Rustin P, Fischer A, Saudubray J-M, Munnich A 1990 Pearson's marrowpancreas syndrome. J Clin Invest 86:1601-1608

9. Roetig A, M Colonna M, Bonnefont J-P, Blanche S. Fischer A, Saudubray JM, Munnich A 1989 Mitochondrial DNA deletions in Pearson's marrow/ pancreas syndrome. Lancet 1:902-903

10. Cormier V, Roetig A, Quartino AR, Forni GL, Cerone R, Maier M, Saudubray
J-M, Munnich A 1990 Widespread multitissue deletions of the mitochondrial genome in the Pearson marrow-pancreas syndrome. J Pediatr 117: 599-602 11. Anderson MA, Gusella JF 1984 Use of cyclosporin-A in establishing EpsteinBarr virus transformed human lymphoblastoid cell lines. In Vitro 21: 856858

12. Miller G, Lipman M 1973 Release of infectious Epstein-Barr virus by transformed marmoset leukocytes. Proc Natl Acad Sci USA 70:190-194

13. Old JM 1986 Fetal DNA analysis. In: Davies KE (ed) Human Genetic Diseases: A Practical Approach. IRL Press, Oxford, UK, pp 1-18

14. Anderson S, Bankier AT, Barrell BG de Bruijn MHL, Coulson AR, Drouin J Eperon IC, Nierlich DP, Roe BA, Sanger F, Schreier PH, Smith AJH, Staden $\mathrm{R}$, Young IG 1981 Sequence and organization of the mitochondrial genome. Nature 290:457-465

15. Holt IJ, Harding AE, Morgan-Hughes JA 1989 Deletions of muscle mitochondrial DNA in mitochondrial myopathies: sequence analysis and possible mechanisms. Nucleic Acids Res 17:4465-4469

16. Roetig A, Cormier V, Koll F, Mize CE, Saudubray J-M, Veerman A, Pearson HA, Munnich A 1991 Site-specific deletions of the mitochondrial genome in the Pearson marrow-pancreas syndrome. Genomics 10:502-504

17. Schon EA, Rizzuto R, Moraes CT, Nakase H, Zeviani M, DiMauro S 1989 A direct repeat is a hotspot for large-scale deletion of human mitochondrial DNA. Science 244:346-349

18. Nakase H, Moraes CT, Rizzuto R, Lombes A, DiMauro S, Schon EA 1990 Transcription and translation of deleted mitochondrial genomes in KearnsSayre syndrome: implications for pathogenesis. Am J Hum Genet 46:418427

19. Shoubridge EA, Karpati G, Hastings KEM 1990 Deletion mutants are functionally dominant over wild-type mitochondrial genomes in skeletal muscle fiber segments in mitochondrial disease. Cell 62:43-49 